\title{
Evaluation of Digital Optical Density of Bone Repair in Rats Medicated with Ketoprofen
}

\author{
Márcia Valéria MARTINS ${ }^{1}$ \\ Marcos André dos Santos da SILVA ${ }^{1}$ \\ Edmundo MEDICI FILHO ${ }^{1}$ \\ Luiz Cesar de MORAES ${ }^{1}$ \\ Julio Cezar de Melo CASTILHO ${ }^{1}$ \\ Rosilene Fernandes da ROCHA ${ }^{2}$ \\ ${ }^{1}$ Department of Surgery, Periodontology and Radiology and ${ }^{2}$ Department of Biosciences and Oral Diagnosis, Faculty of
Dentistry of São José dos Campos, São Paulo State University (UNESP), São José dos Campos, SP, Brazil \\ The purpose of this study was to evaluate the influence of ketoprofen on bone repair process in tibiae of rats by means of analysis of \\ the digital optical density. Twenty Wistar rats were assigned to two groups: an untreated control group and a group treated with \\ ketoprofen. The experimental procedures comprised the following stages: general anesthesia, preparation of a unicortical bone defect \\ on the left tibia of each rat, medication with ketoprofen and radiographic examination. Digital radiographic images were acquired using \\ Visualix GX-S-HDI ${ }^{\mathrm{TM}}$ digital sensor and an X-ray equipment. Radiographs were taken at baseline, 7, 14, 21 and 30 days postoperatively \\ and the optical density (OD) was evaluated using the Vix win ${ }^{\mathrm{TM}} 1.4$ system. The mean values of OD readings were analyzed \\ statistically by ANOVA and Tukey's test with significance level set at á=5\%. The control group showed a statistically significant \\ correlation $(\mathrm{p}=0.001)$ between time and optical density, while the ketoprofen group exhibited a weak and not statistically significant \\ correlation $(\mathrm{p}=0.100)$. The control group presented the smallest OD ratios at days 1 and 7 , and the greatest OD ratios at days 14,21 \\ and 30 , with statistically significant difference $(\mathrm{p}=0.001)$. There was no significant differences $(\mathrm{p}=0.100)$ among the OD ratios in the \\ ketoprofen group, regardless of the evaluation period. The findings of this study suggest that ketoprofen influenced bone repair process \\ because there was an increase in optical density during the first week and delayed new bone formation after the 21st day.
}

Key words: bone repair, ketoprofen, digital optical density, direct digital radiograph.

\section{INTRODUCTION}

Anti-inflammatory drugs are employed to reduce or control an inflammatory process because they inhibit the synthesis of inflammation mediators (prostaglandins) and are therefore largely useful in medical and dental specialties alike.

Non-steroidal anti-inflammatory drugs (NSAIDs) are competitive inhibitors of the cyclooxygenase enzyme (COX), which is in charge of the biosynthesis of prostaglandins and thromboxanes from the arachidonic acid (1-3). Two forms of the cyclooxygenase enzyme have been described, COX-1 and COX-2. Ketoprofen is a specific inhibitor of COX-1 (3).

Current studies have associated the intake of
NSAIDs with bone repair process $(2,4,5)$ and have demonstrated that bone is one of the few tissues with remodeling capacity, being able to recover its structure and function even after a trauma.

Direct digital radiography has been largely used in studies investigating bone defects because this methodology is as efficient as conventional radiographic techniques for detection of incipient bone lesions and offers technical resources and tools (softwares) that assist in visualization, delimitation and measurement of these lesions $(6,7)$.

The purpose of this study was to evaluate the influence of ketoprofen on the bone repair of unicortical defects created in tibiae of rats by analysis of the digital optical density (OD) at different periods of time. 


\section{MATERIAL AND METHODS}

Twenty adult male rats from the same line (Rattus norvegicus albinus, Wistar) aged around 120 days and weighing from 350 to 400 g were obtained from the Animal Laboratory of the Faculty of Dentistry of São Jose dos Campos (UNESP). The animals were housed in proper cages and environment and were maintained on laboratory chow (Labina) and water ad libitum.

The animals were anesthetized with $2 \%$ aqueous solution of 2-(2,6-xylidine)-5,6-dihydro-4H-1,3-thiazine hydrochloride (Rompum; Bayer do Brasil SA, São Paulo, SP, Brazil) and ketamine (Francotar; Virbac do Brasil Ind. Com Ltda, São Paulo, SP, Brazil.) at a 1:0.5

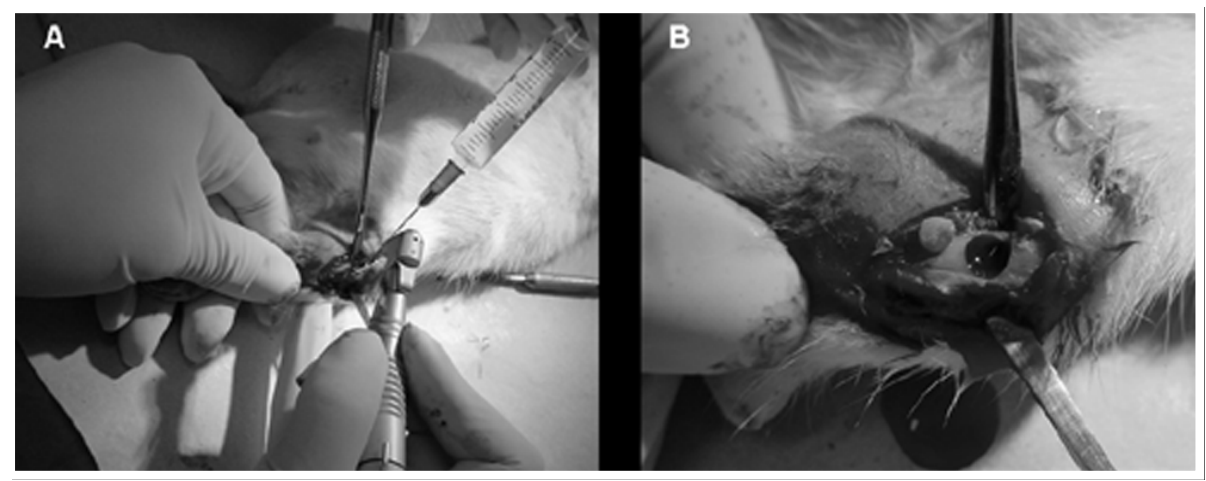

Figure 1. A. Perforation being made on rat left tibia; B. Unicortical bone defect.

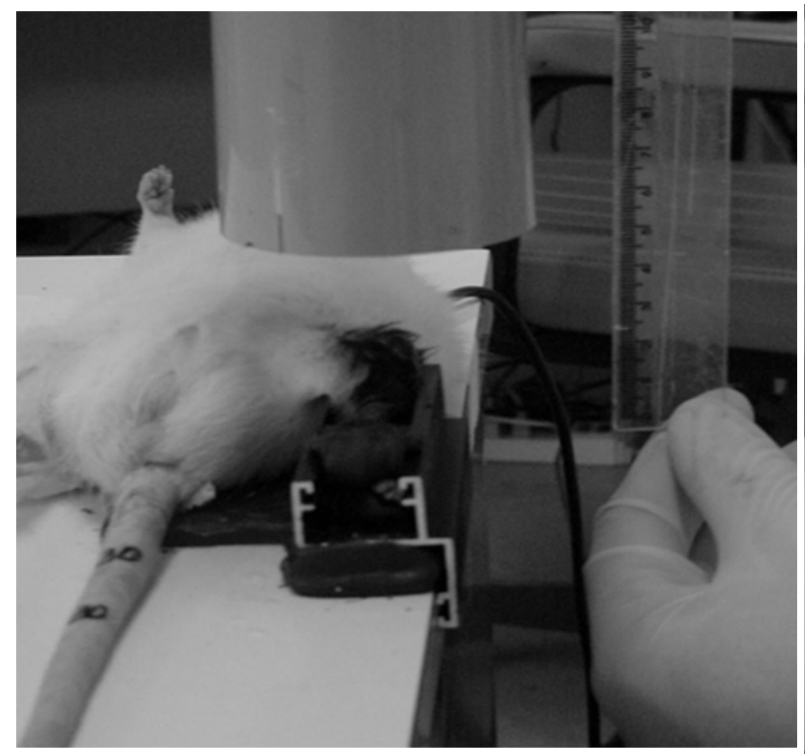

Figure 2. Acquisition of the radiographic image after placement of the digital sensor in the tibia of the rat.
$\mathrm{mL}$ ratio and dose of $0.1 \mathrm{~mL} / 100 \mathrm{mg}$. The rats were previously weighed to confirm the correct dose to be administered. Hypodermic insulin syringes with intradermal needles were used.

The skin over the left tibia was shaved and antisepsis was performed with iodized alcohol. An incision was made on the proximal area of the tibia with an interchangeable \#15 blade mounted on a Bard-Parker handle and a \#7 spatula was used to retract the soft tissues and periosteum. A perforation was made on the bone with a 3-mm diameter trephine bur coupled to an electric engine (Kavo do Brasil S.A, Joinville, SC, Brazil) at 1,100 rpm speed and under constant irrigation with saline (Fig. $1 \mathrm{~A}$ and B). Skin was sutured with silk suture number 4 (Ethicon-Johnson \& Johnson, Somerville, NJ, USA) and antisepsis was done with iodized alcohol

Ten animals were medicated with ketoprofen (Merck \& Co., Inc., Whitehouse Station, NJ, USA) at a dose of $12.5 \mathrm{mg} /$ day for 30 days and 10 animals were not medicated (control).

For the radiographic examination, the rats in the control and ketoprofen groups were initially submitted to general anesthesia by application of the same anesthetics, syringes and needles used for surgery, although the anesthetic dose in this stage ranged from 0.08 to $0.1 \mathrm{~mL}$. Thereafter, each rat was positioned in dorsal recumbency on a supporting table. Before the baseline direct digital radiographs were obtained, an impression was taken from the left tibia with low fusion impression compound (Godibar; Lysanda Produtos Odontológicos, São Paulo, SP, Brazil), in a way that the initial position could be reproduced in the further stages. Impression was taken on the lower portion of an individual metallic clamping device shaped as a rectangular box, with 3 free ends and a groove for fixation on the supporting table (Fig. 2). Visualix GX-S-HDI ${ }^{\mathrm{TM}}$ digital sensor (Gendex Dental System, Dentsply International, Chicago, IL, USA) was placed on the lower portion (free from impression material) of each device. Because it is a CCD (Charge-Coupled Device) sensor, the image could be immediately transmitted to a computer screen. 
Thereafter, the tibia was introduced in the clamping device, positioned on the upper portion of the sensor and fixated to the device and impression mould with \#9 utility wax (Epoxiglass Ind. Com. de Produtos Químicos Ltda, Diadema, SP, Brazil). In this way, the bone defect was also turned upwards and the initial position could be reproduced in all evaluation periods (Fig. 2). Afterwards, the left tibia of each rat was radiographed with an X-ray equipment (SPECTRO-70X ${ }^{\mathrm{TM}}$; Dabi Atlante, São Paulo, SP, Brazil) at $10 \mathrm{~mA}$ and $65 \mathrm{kVp}$, with $0.10 \mathrm{~s}$ exposure time and $25 \mathrm{~cm}$ focus-object distance (Fig. 2). Radiographs were taken from rats in both control group (Fig. 3 A-E) and ketoprofen group (Fig. 4 A-E) at baseline and 7, 14, 21 and 30 days after the unicortical bone defects were created on the left tibia of the animals.

Optical density was evaluated using the Vix win $^{\text {TM }} 1.4$ system (Gendex Dental System). The mean values of OD readings were analyzed statistically by ANOVA and Tukey's test at 5\% significance level.

\section{RESULTS}

The control group had a moderate and statistically significant correlation by ANOVA ( $\mathrm{p}=0.001$ ) between time and OD ratios (Fig. 5), while the ketoprofen group exhibited a weak and not statistically significant correlation by ANOVA ( $\mathrm{p}=0.100$ ) (Fig. 6).

Tukey's test (á $=5 \%)$ showed that the control group presented the smallest OD ratios (\%) at days 1 $(0.89 \pm 0.04)$ and $7(0.88 \pm 0.05)$ and the greatest OD ratios (\%) at days $14(0.94 \pm 0.02), 21(0.95 \pm 0.02)$ and $30(0.96 \pm 0.01)$ with a statistically significant difference $(\mathrm{p}=0.001)$ (Fig. 3).

For the ketoprofen group, there were no statistically significant differences $(p=0.100)$ among the evaluation periods. The ketoprofen group presented greater ratios than the control group up to 21st day, after which, the values decreased until reach smaller rations than the control group at the 30th day.

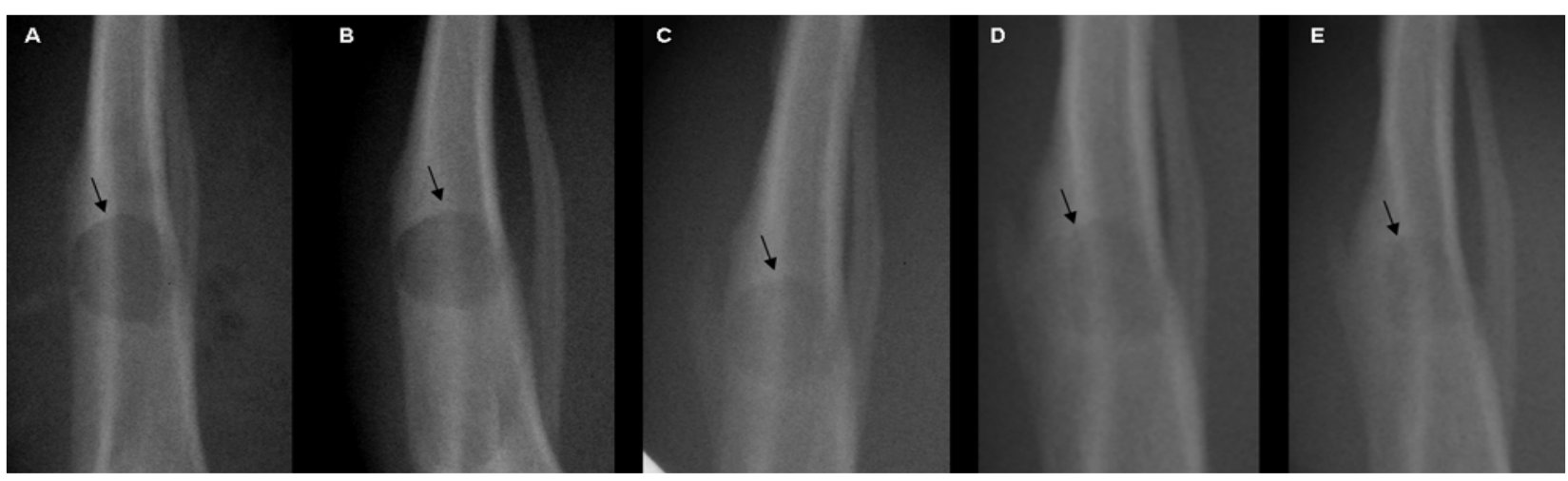

Figure 3. Radiographic examination of the control group. A: Baseline; B: 7th day; C: 14th day; D: 21st day; E: 30th day.

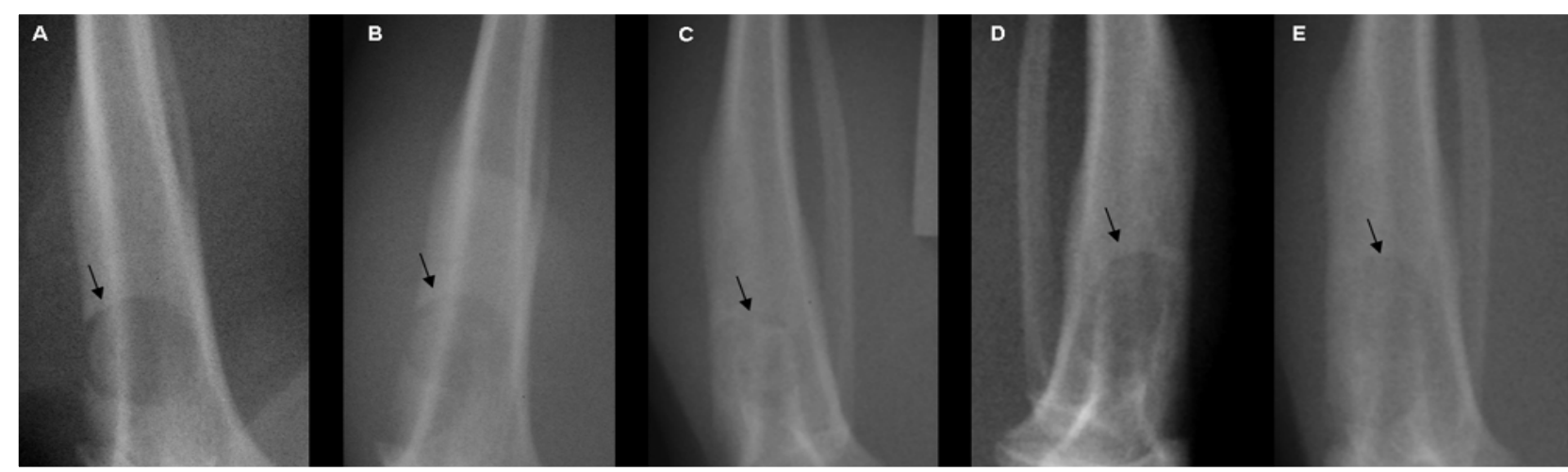

Figure 4: Radiographic examination of the ketoprofen group. A: Baseline; B: 7th day; C: 14th day; D: 21st day; E: 30th day. 


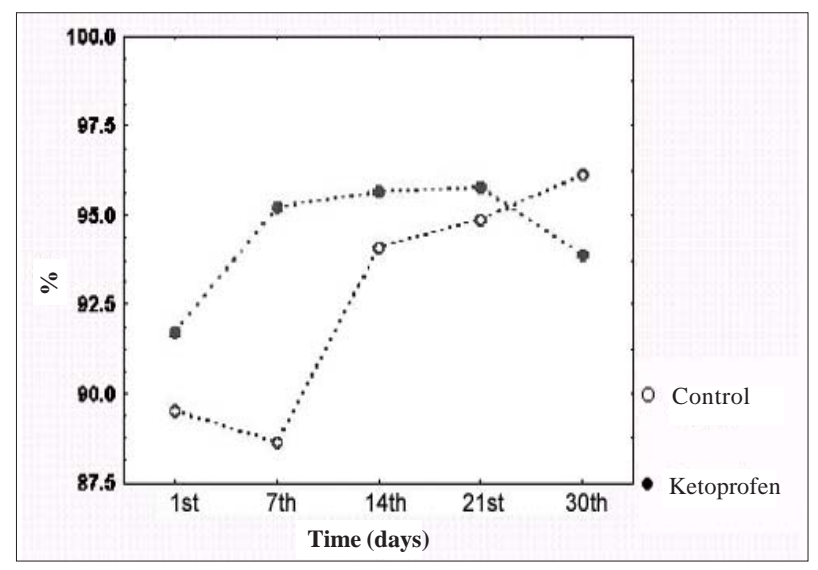

Figure 5. Means of optical density ratios as a function of time.

\section{DISCUSSION}

With the recent technological advance, radiographic techniques have improved remarkably and conventional dental radiography is being progressively surpassed by digital radiography. Some years ago, emphasis was given on indirect digital radiograph, which involved conversion of a conventional radiographic image into a digital image. This period was useful for research and development of direct digital radiographic techniques (8).

Even though some studies have stated that there are no differences between conventional and digital radiographs with respect to the image resolution and detection of bone lesions (6,7,9-12), a direct digital system was used in this study because it has several advantages over conventional techniques. Digital radiographic systems produce standard image resolution with significant reduction of exposure time and working time, no need for chemical development and possibility of using image manipulation resources that improve the assessment and measurement of the optical density of anatomical structures, pathological processes and experimentally-induced bone defects by means of specific softwares $(8,13,14)$.

NSAIDs have been shown to effectively inhibit the production of inflammation mediators (prostaglandins and thromboxanes) and are the drugs of choice against inflammatory processes affecting joints, tendons and muscles $(1,15)$. Animal studies have been conducted to investigate the influence of NSAIDs on bone repair process and these drugs have been shown to stimulate

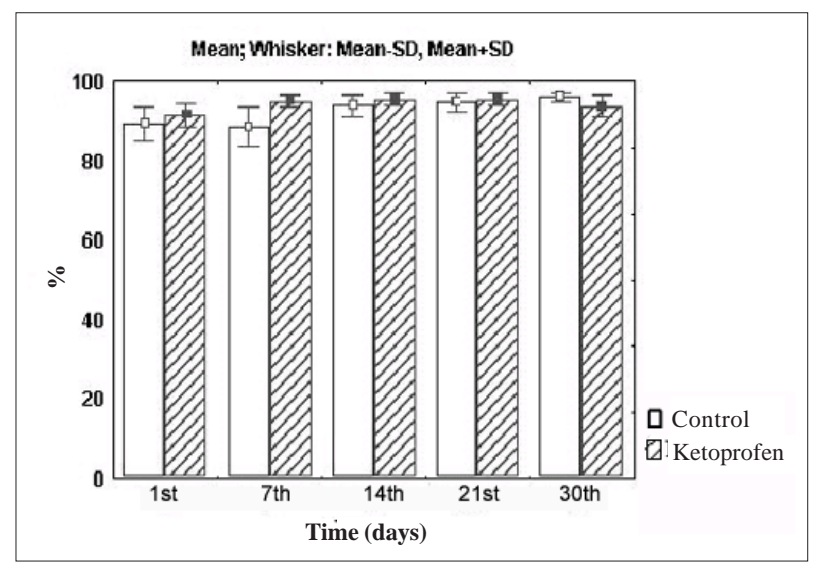

Figure 6. Means of optical density ratios and shunting line standard as a function of time.

bone healing $(4-5,16)$. However, it has also been reported that NSAIDs may inhibit bone repair depending on the type of drug, period of intake and dosage administered $(1,15,17,18)$. The findings of the present study are consistent with the latter results. Other authors, however, have supported that the use of NSAIDs do not interfere with bone remodeling process (5).

Studies in humans with periodontal disease have also been conducted to assess the influence of NSAIDs on bone repair process. Bragger et al. (19) stated that the administration of NSAIDs did not influence bone healing in subjects with advanced periodontitis and concluded that the prescription of such drugs was not justified. Ketoprofen is a NSAID that has been employed by several authors at different doses, intervals and means of administration.

$\mathrm{Li}$ et al. (4) used topical ketoprofen in Rhesus (Macaca mulata) monkeys with periodontal disease at a dose of $1.8 \mathrm{~mL} /$ day for 6 months. Radiographs were taken 2 weeks preoperatively, at baseline and 3 and 6 months after surgery. The radiographic findings revealed positive effects on the activity of the alveolar bone in the group treated with ketoprofen 1 month after treatment, whereas the control group showed bone loss within the same time period. Zeng et al. (20) investigated the effect of S-ketoprofen in Weanling rats (45 female aged 4 weeks) after tenotomy, which were simultaneously treated with $0,0.02,0.1,0.5$ or $2.5 \mathrm{mg} / \mathrm{kg}$ of $\mathrm{S}$ ketoprofen for 21 days. The authors observed that the administration of higher doses of this drug yielded a reduction of the area of cancellous bone and an increase in bone trabeculae. Paquette et al. (2) evaluated the 
pharmacodynamic effect of ketoprofen (administered either topically or systemically during 22 days) on the prostaglandins of the gingival fluid of 42 individuals aged 35-57 years with moderate to severe periodontal disease. The authors concluded that all dosages of ketoprofen pharmacologically reduced the prostaglandin levels on the gingival fluid of the patients, thus inhibiting disease progression.

The results of the present study do not agree with those of the above-mentioned investigations $(2,4,20)$. Unlike these authors, we have observed that the dosage and period of administration of a NSAID directly interfered with its mechanism of action because OD values of the unicortical bone defects created in tibiae of rats increased in both ketoprofen-treated (daily oral dose of $12.5 \mathrm{mg} / \mathrm{kg}$ for 30 days) and control groups up to the 21st day, with greater OD values for the ketoprofen group. After this period, OD values in the treated group decreased until reach smaller values than the control group at 30th day.

These findings indicate a negative influence of ketoprofen on bone repair process when administered for more than 21 days.

\section{RESUMO}

O objetivo deste estudo foi avaliar a influência do cetoprofeno sobre o processo de reparação óssea em tíbias de ratos, por meio da análise da densidade óptica digital. Vinte ratos da linhagem Wistar foram divididos em 2 grupos: um grupo controle (sem tratamento) e um grupo tratado com cetoprofeno. Os procedimentos experimentais consistiram de: anestesia, cirurgia, administração do cetoprofeno e exame radiográfico. As imagens radiográficas foram adquiridas empregando-se o sensor digital Visualix GX-S-HDI ${ }^{\mathrm{TM}}$ e um aparelho de raios X. As radiografias foram realizadas nos períodos baseline (inicial), 7, 14, 21 e 30 dias pós-operatório, sendo a densidade óptica (DO) avaliada por meio do sistema Vix win ${ }^{\mathrm{TM}} 1.4$. Os valores médios da leitura da DO obtidos foram analisados estatisticamente por meio de ANOVA e teste de Tukey com nível de significância de 5\%. No grupo controle, houve diferença estatisticamente significante $(p=0,001)$ entre o tempo e a DO, enquanto no grupo tratado com cetoprofeno a diferença não foi estatisticamente significante $(p=0,100)$. O grupo controle apresentou as menores proporções de DO (\%) no $1^{\circ}$ e 70 dias e as maiores proporções de DO (\%) no $14^{\circ}, 21^{\circ}$ e $30^{\circ}$ dias, com diferença estatisticamente significante $(p=0,001)$. Não houve diferença estatisticamente significante $(\mathrm{p}=0,100)$ entre as proporções médias de DO (\%) no grupo tratado, independentemente do período de avaliação. Os achados deste trabalho sugerem que houve influência do cetoprofeno sobre o processo de reparo ósseo, uma vez que na primeira semana o medicamento proporcionou aumento na densidade óptica e provocou atraso na neoformação óssea após o 21ํㅡㄹ.

\section{REFERENCES}

1. Ho ML, Chang JK, Chuang LY, Hsu HK, Wang GJ. Effects of nonsteroidal anti-inflamatory drugs and prostaglandins on osteoblastic functions. Biochem Pharmacol 1999;58:983990.

2. Paquette DW, Lawrence HP, McCombs GB, Wilder R, Binder TA, Troullos E, Annett M, Friedman M, Smith PC, Offenbacher S. Pharmacodynamic effects of ketoprofen on crevicular fluid prostanoids in adult periodontitis. J Clin Periodontol 2000;27:558-566.

3. Llorens O, Perez JJ, Palomer A, Mauleon D. Differential binding mode of diversy cyclooxygenase inhibitors. J Mol Graph Model 2002;20:359-371.

4. Li KL, Vogel R, Jeffcoat MK, Alfano MC, Smith MA, Collins JG, Offenbacher S. The effect of ketoprofen creams on periodontal disease in rhesus monkeys. J Periodontal Res 1996;31:525-532.

5. de Lima V, Bezerra MM, de Menezes Alencar VB, Vidal FD, da Rocha FA, de Castro Brito GA, de Albuquerque Ribeiro R. Effects of chlorpromazine on alveolar bone loss in experimental periodontal disease in rats. Eur J Oral Sci 2000;108:123-129.

6. Holtzmann DJ, Johnson WT, Southard TE, Khademi JA, Chang PJ, Rivera EM. Storage-phosphor computed radiography versus film radiography in the detection of pathologic periradicular bone loss in cadavers. Oral Surg Oral Med Oral Pathol Oral Radiol Endod 1998;86:90-97.

7. Kaeppler G, Vogel A, Axmann-Krcmar D. Intra-oral storage phosphor and conventional radiography in the assessment of alveolar bone structures. Dentomaxillofac Radiol 2000;29:362-367.

8. Wenzel A, Grondahl HG. Direct digital radiography in the dental office. Int Dent J 1995;45:27-34.

9. Thaete FL, Fuhrman CR, Oliver JH, Britton CA, Campbell WL, Feist JH, Straub WH, Davis PL, Plunkett MB. Digital radiography and conventional imaging of the chest: a comparison of observer performance. AJR Am J Roentgenol 1994;162:575-581.

10. Stassinakis A, Zeyer O, Bragger U. The diagnosis of bone lesions with conventional $\mathrm{x}$-ray images and with a direct digital procedure (RVG). Scweiz Monatsschr Zahnmed 1995; 105:1539-45.

11. Kullendorff B, Nilsson M, Rohlin M. Diagnostic accuracy of direct digital dental radiography for the detection of periapical bone lesions: overall comparison between conventional and direct digital radiography. Oral Surg Oral Med Oral Pathol Oral Radiol Endod 1996;82:344-350.

12. Mistak EJ, Loushine RJ, Primack PD, West LA, Runyan DA. Interpretation of periapical lesions comparing conventional, direct digital, and telephonically transmitted radiographic images. J Endod 1998;24:262-266.

13. Meier AW, Brown CE, Miles DA, Analoui M. Interpretation of chemically created periapical lesions using direct digital imaging. J Endod 1996;22:516-520.

14. Wenzel A. Effect of image enhancement for detectability of bone lesions in digitized intraoral radiographs. Scand J Dent Res 1988;96:149-60.

15. Yazdi M, Cheung DT, Cobble S, Nimni ME, Schonfeld SE. Effects of non-steroidal anti-inflammatory drugs on demineralized bone-induced bone formation. J Periodontal Res 1992;27:28-33. 
16. Offenbacher S, Williams RC, Jeffcoat MK, Howell TH, Odle BM, Smith MA, Hall CM, Johnson HG, Goldhaber P. Effects of NSAIDs on beagle crevicular cyclooxygenase metabolites and periodontal bone loss. J Periodontal Res 1992;27:207213.

17. Allen HL, Wase A, Bear WT. Indomethacin and aspirin: effect of nonsteroidal anti-inflammatory agents on the rate of fracture repair in the rat. Acta Orthop Scand 1980;51:595600 .
18. Altman, R.D. Altman RD, Latta LL, Keer R, Renfree K, Hornicek FJ, Banovac K. Effect of nonsterioidal antiinflammatory drugs on fracture healing: a laboratory study in rats. J Orthop Trauma 1995;9:392-400.

19. Bragger U, Muhle T, Fourmousis I, Lang NP, Mombelli A. Effect of the NSAID flurbiprofen on remodelling after periodontal surgery. J Periodontal Res 1997;32:575-582.

20. Zeng QQ, Jee WS, Ke HZ, Wechter WJ. S-ketoprofen inhibits tenotomy-induced bone loss and dynamics in weanling rats. Bone Miner 1993;21:203-218.

Accepted August 24, 2004 